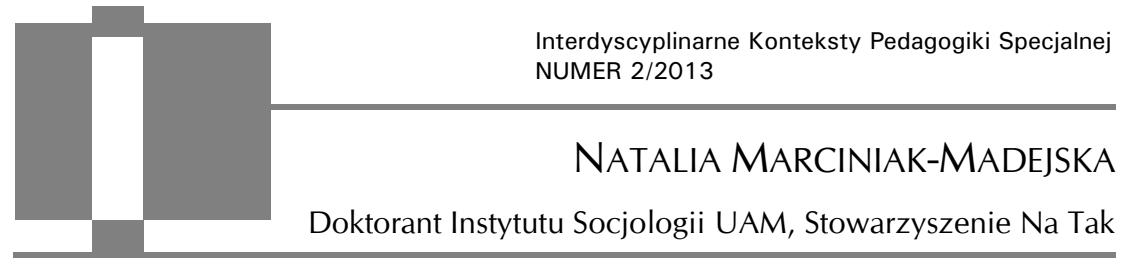

\title{
Życie dorosłych osób z niepełnosprawnością intelektualną - problematyczność realizacji potrzeby seksualności i niezależności w perspektywie rozwoju tożsamości
}

\begin{abstract}
Marciniak-Madejska Natalia, The life of adults with intellectual disabilities a problematic implementation of necessary sexuality and independence in the context of the development of identity [Życie dorosłych osób z niepełnosprawnością intelektualną problematyczność realizacji potrzeby seksualności i niezależności w perspektywie rozwoju tożsamości]. Interdyscyplinarne Konteksty Pedagogiki Specjalnej, nr 2, Poznań 2013. Pp. 115-131. Adam Mickiewicz University Press. ISBN 978-83-232-2594-2. ISSN 2300-391X.

The author emphasizes the influence of social attitudes towards an individual on his or her self-perception and also pays attention to what threatens the development of identity in people with intellectual disability. It is said that the most important thing in the process of identity formation is the fulfillment of three basic psychological needs during adulthood: the need for having positive relations with other people, the need for autonomy and the need for competence. The limited opportunities of adult women and men with intellectual disability to realize these needs are connected to attitudes towards people with intellectual disability such as overprotectiveness, compassion, focus on deficits, ignorance, segregation, control and judgments. These attitudes are generated by a set of social stereotypes, according to which a person with intellectual disability is an "ageless child". People with intellectual disabilities are affected by a lack of autonomy, the impossibility of experiencing their own competence as well as limited social contacts as they stay under control of
\end{abstract}


their closest social environment. These problems are concerned with the areas of sexuality and independent living. The author provides examples of discriminatory attitudes as well as current stereotypes and social beliefs which are an actual barrier to the psychosocial functioning of adult people with intellectual disability with respect to the realization of their sexual needs and needs for autonomy.

KEY WORDS: people with intellectual disability, identity, sexuality, assisted housing

\section{Wprowadzenie}

Wiek XX był okresem rozwoju koncepcji na temat tożsamości człowieka, jego relacji z samym sobą i innymi ludźmi. Podejmowano dyskusje dotyczące prawa jednostki do wolnego wyboru, wpływu na własny los, decydowania o tym, kim chce być i jak chce prowadzić swoje życie.

Próba odpowiedzi na pytanie, kim jestem i dokąd zmierzam, wymaga obecności jednostki w życiu społecznym, doświadczania oraz eksplorowania przestrzeni, nawiązywania relacji i zrywania ich, podejmowania decyzji, a także uczenia się na własnych błędach. Otwiera to drzwi do rozwoju tożsamości, znalezienia swojego miejsca $\mathrm{w}$ świecie, osadzenia $\mathrm{w}$ rolach najbardziej zgodnych $\mathrm{z}$ osobistymi przekonaniami i wartościami.

Tożsamość określana jest na dwóch płaszczyznach: indywidualnej i społecznej ${ }^{1}$. Tożsamość indywidualna (jednostkowa) obejmuje: wgląd w siebie samego (samowiedza), poczucie odrębności, znajomość własnych potrzeb, reakcji obronnych, systemu wartości, cech osobowości (takich jak charakter, przekonania, zainteresowania). Tożsamość społeczna z kolei kształtowana jest przez innych ludzi, którzy przypisują jednostce określone cechy. Ma związek z zajmowaną pozycją społeczną i rolami pełnionymi w życiu codziennym.

Związek tożsamości jednostkowej i społecznej jest znaczący. Jednostka postrzega siebie przez pryzmat przynależności do okre-

1 Podaję za: M. Golka, Socjologia kultury, Wyd. Nauk. Scholar, Warszawa 2007, s. 115 . 
ślonych grup, ocenia siebie na podstawie pełnionych funkcji i realizowanych ról społecznych. To społeczeństwo dostarcza jednostce informacji, które wpływają na jej autopercepcję, samoocenę, zachowanie, w tym gotowość do podejmowania działań i integracji ze społeczeństwem.

\section{Procesualny charakter budowania tożsamości osoby z niepełnosprawnością intelektualną - uwagi wstępne o zagrożeniach realizacji potrzeb, zadań i ról społecznych}

Budowanie tożsamości ma charakter procesualny - trwa całe życie, choć w pierwszych teoriach na ten temat (m.in. E.H. Eriksona) zwracano uwagę na szczególne znaczenie okresu adolescencji. W tym czasie człowiek ma już umiejętności kształtowane na wcześniejszych etapach życia, które w istotny sposób wpływają na formowanie się jego tożsamości²:

1) umiejętność inicjowania i utrzymania kontaktów $\mathrm{z}$ innymi ludźmi oparta na zaufaniu,

2) poczucie odrębności od rodziców czy opiekunów wspierane wzrostem samodzielności w wykonywaniu coraz szerszej gamy czynności dnia codziennego,

3) inicjatywa w podejmowanych działaniach, stanowczość, pokonywanie barier,

4) poczucie kompetencji dzięki doświadczaniu sukcesów i umiejętności współdziałania z innymi.

Kompetencje te stanowią rezultat zaspokojenia trzech podstawowych potrzeb psychicznych człowieka: potrzeby utrzymania pozytywnych relacji z innymi, potrzeby autonomii i potrzeby kompetencji. Wśród różnych kategorii społecznych zagrożonych doświadczeniem frustracji tych potrzeb osoby z niepełnosprawnością

${ }^{2}$ M. Rękosiewicz, $W$ drodze do dorosłości. Tożsamość osób z niepetnosprawnością intelektualna, TIPI, Wielichowo 2012, s. 35. 
intelektualną zajmują szczególne miejsce ${ }^{3}$. Tezę tę potwierdza wiele badań nad funkcjonowaniem osób z niepełnosprawnością intelektualną w okresie dorosłości4. Większość badaczy wykazuje, iż osoby z niepełną sprawnością od najbliższego otoczenia uzyskują mniejsze prawo do autonomii niż ich zdrowi rówieśnicy. Przeciwnie niż od pozostałych grup społecznych, od osób niepełnosprawnych intelektualnie oczekuje się postawy biernej, zależnej oraz poddawania się kontroli i ciągłej ocenie ${ }^{5}$. Oczekiwania te generowane są przez system stereotypów społecznych 6 . Znaczącą rolę przypisuje się stereotypom wyglądu i funkcjonowania osób z niepełnosprawnością intelektualną, które z uwagi na swoją odmienność budzą niepokój, zdziwienie, litość 7 . Stereotypy wpływają tym samym na postawy społeczne wobec osób z niepełnosprawnością. Mogą one przyjąć formę zgeneralizowaną, polegającą na identyfikowaniu osób niepełnosprawnych jako odmiennych od sprawnej części społeczeń-

${ }^{3}$ M. Rękosiewicz, dz. cyt., s. 35.

4 Por. przegląd badań nad funkcjonowaniem w okresie dorosłości dokonany przez A. Zawiślak w: A. Zawiślak, Jakość życia osób dorostych z niepetnosprawnościa intelektualna, DIFIN, Warszawa 2011, s. 36-40.

${ }^{5}$ Upośledzające działanie otoczenia w literaturze przedmiotu nazywane jest „wtórnym skutkiem niepełnosprawności”. Zwraca się uwagę, że potencjał jednostki zawsze realizuje się w określonym otoczeniu społecznym i fizycznym. Zakres możliwości funkcjonalnych weryfikowany jest wszędzie tam, gdzie jednostka podejmuje działania związane z realizacją codziennych zadań życiowych. Cyt. za: Z. Woźniak, Niepetnosprawność i niepetnosprawni w polityce społecznej. Społeczny kontekst medycznego problemu, SWPS Academia, Warszawa 2008, s. 83.

${ }^{6}$ Stereotypy to kategorie cechujące się nadmiernym uproszczeniem, nasyceniem, wartościowaniem (dodatnim lub ujemnym), generalizacją cech jednostki na wszystkich reprezentantów danej grupy, zawierające tendencyjne, stronnicze, niezweryfikowane uogólnienia, najczęściej fałszywe lub nadmiernie uproszczone. Cyt. za: W. Dykcik, Tendencje rozwoju pedagogiki specjalnej. Osiagnięcia naukowe i praktyka (z perspektywy 50-lecia pracy pedagogicznej $z$ osobami z niepetnosprawnościa), Wyd. Nauk. Polskiego Towarzystwa Pedagogicznego Oddział w Poznaniu, Poznań 2010, s. $248-249$.

7 Por. teoria piętna E. Goffmana, w której została rozwinięta analiza zjawiska napiętnowania społecznego oraz sposobów i symboli służących napiętnowaniu: E. Goffman, Piętno. Rozważania o zranionej tożsamości, GWP, Gdańsk 2005, s. 31-76. 
stwa, lub zindywidualizowaną, zależną od rodzaju, stopnia i widzialności niepełnosprawności ${ }^{8}$. Postawy społeczne generują bariery psychospołeczne wyrażane poprzez poziom partycypacji społecznej lub izolacji i ignorancji otoczenia osób niepełnosprawnych.

Wpisane w dorosłość zadania i role społeczne, których realizacja kształtuje tożsamość jednostkową, są sferą często odbieraną osobom z niepełnosprawnościami. Typowa dla okresu adolescencji zmiana stosunku względem rodziców z zależnego na partnerski zagrożona jest potrzebą wsparcia osoby niepełnosprawnej w wykonywaniu codziennych czynności. Utrwalany jest tym samym stereotypowy obraz „wiecznego dziecka”, który mimo wieku biologicznego wciąż potrzebuje opieki osób dorosłych. Wobec osoby z niepełnosprawnością przejawiane są postawy dyrektywne, zależnościowe, nadopiekuńcze. Również istotne dla tego okresu przejście od pozycji „pasywnej” do „aktywnej” jest trudne z uwagi na ciągłą kontrolę i ocenę opiekunów ${ }^{9}$.

Istotny wpływ na występowanie psychospołecznych barier funkcjonowania społecznego osób z niepełnosprawnością intelektualną ma system rodzinny cechujący się nadmiernym otaczaniem opieką. Chronienie osoby przed sytuacjami trudnymi powoduje, że nie ma ona możliwości wypracowania własnych kompetencji, mechanizmów obronnych, zbudowania poczucia własnej wartości, co w późniejszym życiu owocuje silną obawą przed skrzywdzeniem ze strony otoczenia (następuje wycofanie się z większości stosunków społecznych). Pozostając w ciągłej zależności, jednostka może mieć problem z osiągnięciem pełnej dojrzałości, w tym dojrzałości społecznej. Pozostawanie pod wpływem rodziny owocuje także niskim uczestnictwem społecznym (wycofanie się do bezwarunkowo akceptujących kręgów osób najbliższych) ${ }^{10}$. Brak umiejętności utrzy-

${ }^{8}$ Por. Z. Woźniak, dz. cyt., s. 97.

${ }^{9}$ Por. F. Wojciechowski, Problemy adolescencji. Postepowanie profilaktyczne i pomocowe w kontekście niepetnosprawności, [w:] T. Żółkowska (red.), Społeczno-pedagogiczne konteksty niepetnosprawności, US, Szczecin 2011, s. 61.

${ }^{10}$ M. Chruściak, J. Michalczuk, K. Sijko, D. Wiszejko-Wierzbicka, D. Życzyńska-Ciołek, Bariery aktywności zawodowej oraz czynniki sprzyjajace podejmowaniu i utrzy- 
mania pozytywnych relacji $\mathrm{z}$ innymi osobami, brak autonomii i niespełnienie potrzeby kompetencji obniżają poziom motywacji osoby z niepełnosprawnością do uczestnictwa w życiu społecznym i w konsekwencji przekłada się na zaburzenia rozwoju tożsamości dorosłej osoby z niepełnosprawnością intelektualną.

Brak autonomii oraz ciągła kontrola osób z niepełnosprawnością intelektualną dotyczą szczególnie obszarów życia jednostki, w których ingerencja osób z zewnątrz jest bardzo ograniczona. Wśród nich wciąż rzadko eksplorowany w kontekście rozwoju tożsamości osób niepełnosprawnych jest obszar seksualności i zamieszkania poza rodziną. Są to sfery realizowania zadan życiowych, w których bezpośrednia kontrola opiekunów jest niemożliwa z uwagi na naturalną intymność i niezależność działań podejmowanych w tych obszarach przez jednostkę.

\section{W kręgu realizacji płciowości przez dorosłe osoby z niepełnosprawnością intelektualną}

Seksualność osób z niepełnosprawnością intelektualną jest społecznie niepożądana. W odbiorze społecznym obecne jest niedowierzanie, że osoby niepełnosprawne mogą mieć potrzeby seksualne albo twierdzenie, że to niemoralne, by w tym samym zdaniu mówić o niepełnosprawności i o seksie ${ }^{11}$. Postawa społecznej niechęci wobec seksualności osób z różnego rodzaju dysfunkcjami widoczna jest szczególnie w obszarze regulacji prawnych. W tym kontekście należy wrócić do początku XX w., kiedy rozwijana była koncepcja eugeniki negatywnej12, traktująca osoby niepełnosprawne jako za-

mywaniu pracy, [w:] W. Łukowski, Osoby z ograniczona sprawnościa na rynku pracy portret środowiska, SWPS Academia, Warszawa 2008, s. 132.

11 G. Brearley, Presentation: where did I come from?, Petnoprawni seksualnie - materiały pokonferencyjne, materiały pokonferencyjne - Stowarzyszenie Na Tak, Poznań 2011, s. 7.

12 Eugenika to ruch wywodzący się ze Stanów Zjednoczonych i szybko przeniesiony na grunt europejski. Głównym poglądem głoszonym przez zwolenników 
grożenie dla konkurencyjności gatunku. Konsekwencją tej idei było organizowanie zamkniętych instytucji tworzonych oddzielnie dla kobiet i dla mężczyzn, by uniemożliwić im rozmnażanie. Popularna stała się też sterylizacja kobiet $\mathrm{z}$ różnego rodzaju deficytami ${ }^{13}$. Liberalizacja poglądów na temat seksualności osób z niepełnosprawnością realizowana równolegle z procesami normalizacyjnymi i walką o prawa człowieka, obserwowana $\mathrm{w}$ ramach naszego kręgu cywilizacyjnego od lat 70. XX w., objęła poszanowanie praw osób z dysfunkcją intelektualną do przeżywania własnej seksualności, jej ekspresji, prawa do życia w rodzinie, tworzenia związków małżeńskich i partnerskich, a także posiadania dzieci ${ }^{14}$. Wciąż jednak w ustawodawstwie polskim odnaleźć można zapisy zabraniające zawarcia związku małżeńskiego osobom z niepełnosprawnością intelektualną ${ }^{15}$. Z kolei w polskim kodeksie karnym obowiązują przepisy, które traktują zmuszającego osobę z niepełnosprawnością do obcowania płciowego łagodniej niż jeśli dopuściłby się tego czynu na osobie bez deficytu intelektualnego ${ }^{16}$.

Postawy dyskryminujące seksualność osób z niepełnosprawnością są również widoczne $\mathrm{w}$ aspekcie planowania architektonicznego miejsc użyteczności publicznej. Przykładem może być sposób organizowania toalet publicznych, w których rzadko spotyka się oddzielne dla niepełnosprawnych kobiet i niepełnosprawnych mężczyzn. Co więcej, często spotkać można toalety oddzielne dla mężczyzn oraz wspólne dla kobiet i osób niepełnosprawnych.

Z badań Katarzyny Pawelczak i Moniki Karwackiej ${ }^{17}$ wynika, że społeczeństwo (w tym najbliższe otoczenie) spłaszcza kobiecość

eugeniki było udoskonalenie rasy ludzkiej poprzez odpowiednią selekcję, dobór osobników mających przedłużyć gatunek.

13 Z. Woźniak, dz. cyt., s. 39.

14 M. Kościelska, Niechciana seksualność, Jacek Santorski \& Co, Warszawa 2004, s. 7.

15 Por. Ustawa z dnia 25 lutego 1964 r. Kodeks rodzinny i opiekuńczy, art. 12 § 1.

16 Ustawa z dnia 6 czerwca 1997 r. Kodeks karny, art. 197-198.

${ }^{17}$ K. Pawelczak i M. Karwacka przeprowadziły badania na próbie 17 osób z różnymi rodzajami niepełnosprawności, których problematyka traktuje o poglądach, opiniach i postawach społecznych na temat praw seksualnych osób z niepeł- 
i męskość osób z niepełnosprawnością intelektualną, zaprzeczając ich seksualności. Gill Brearley ${ }^{18}$ zwraca uwagę, że jest to zjawisko powszechne również wśród specjalistów. Relacjonując doświadczenia $\mathrm{w}$ brytyjskich domach pomocy społecznej dla osób z niepełnosprawnością intelektualną, podkreśla, że dyrektorzy tych domów na pytanie, czy ich mieszkańcy wykazują jakieś zachowania seksualne, zazwyczaj odpowiadają: "Nie, u nas nie ma takiego problemu". Wśród podawanych przykładów na uwagę zasługuje historia, gdy pewna matrona $\mathrm{w}$ ogromnym domu opieki dla osób z trudnościami w uczeniu się powiedziała radośnie: „Och, u nas nie ma żadnych problemów związanych z seksem. Ubieramy ich wszystkich w dresy, więc wszyscy wyglądają tak samo i ten problem się nie pojawia"19.

W badaniach Karwackiej i Pawelczak ${ }^{20}$ rozmówcy sygnalizowali, że ich seksualność uznaje się za niewłaściwą, niebezpieczną, problematyczną, taką, którą należy ignorować, a nawet eliminować. Kontrolowanie i tłumienie przejawów seksualności często rozumiane jest jako działanie podejmowane dla dobra osoby niepełno-

nosprawnością. Autorki poszukiwały odpowiedzi na pytanie: Jak osoby z niepełnosprawnościami spostrzegają granice społecznej otwartości na realizację ich potrzeby seksualnej? W badaniach uwidoczniła się pewna prawidłowość. Mając świadomość rozbieżności między deklarowanymi a rzeczywistymi postawami ogółu społeczeństwa wobec przejawów seksualności osób niepełnosprawnych, zmieniły perspektywę analizy badawczej i postanowiły przedstawić punkt widzenia samych osób niepełnosprawnych. Badania zaprezentowane zostały w artykule pt. Granice społecznego przyzwolenia na realizacje praw seksualnych osób z niepetnosprawnościa, Impuls, Kraków 2013 [artykuł w druku].

18 Gill Brearley - wybitna brytyjska terapeutka, pedagog specjalny i fizjoterapeuta, autorka wielu książek z zakresu terapii osób niepełnosprawnych (w języku polskim wydana została jej książka Psychoterapia dzieci niepetnosprawnych ruchowo, WSiP, Warszawa 1999). Relacja na temat doświadczeń w brytyjskich domach pomocy społecznej pochodzi z międzynarodowej konferencji naukowej „Pełnosprawni seksualnie" organizowanej w Poznaniu przez Stowarzyszenie Na Tak w ramach cyklu „Spotkania Na Tak”, 20.05.2011.

19 G. Brearley, dz. cyt., s. 13.

${ }^{20}$ K. Pawelczak, M. Karwacka, Granice społecznego przyzwolenia na realizacje praw seksualnych osób z niepetnosprawnościa, Impuls, Kraków 2013 [artykuł w druku]. 
sprawnej - w ten sposób zapobiega się stawianiu osoby niepełnosprawnej wobec problemów, z którymi nie mogłaby sobie poradzić, na przykład konflikty małżeńskie lub wychowanie potomstwa. Często mamy też do czynienia z nakładaniem na osoby niepełnosprawne moralności rodzica, terapeuty, opiekuna - zakres i poziom moralności opiekuna stanowi punkt odniesienia dla oceny postępowania osoby niepełnosprawnej. W sytuacji, gdy zachowania seksualne postrzegane są jako grzech czy dewiacja, zabrania się osobie z niepełnosprawnością ich przejawiania. Należy jednak pamiętać, że rezygnacja z doznań seksualnych w imię określonych wartości (społecznych czy religijnych) musi być wsparta autentycznym przekonaniem, a nie być formą przymusu, naśladowaniem lub ideą zastępczą. Narzucenie osobie rezygnacji z życia seksualnego grozi kompulsją, nadmiernym skupieniem zainteresowania na obszarze spraw seksualnych ${ }^{21}$.

Podsumowując swoje badania, autorki zaznaczają, że osoby $\mathrm{z}$ niepełnosprawnością, w tym także intelektualną, mogą żyć w związkach, planować i realizować wychowanie potomstwa, a niepełnosprawność rodziców niekoniecznie musi wystąpić u ich potomstwa. Osoby z niepełnosprawnością intelektualną podlegają tym samym fizycznym i hormonalnym przemianom, jak ich rówieśnicy, $z$ tą różnicą, że potrzebują większego wsparcia, aby je zrozumieć, zaakceptować i kontrolować. Ograniczenie możliwości realizacji płciowości jest czynnikiem dyskryminującym i marginalizującym, bowiem rzutuje na całokształt funkcjonowania jednostki22.

Z doświadczeń własnych autorki ${ }^{23}$ niniejszego artykułu wynika, iż rodziny, opiekunowie i specjaliści na co dzień spotykają się

21 Tamże.

22 Tamże.

${ }^{23}$ Natalia Marciniak-Madejska - kierownik Środowiskowego Domu Samopomocy „Kamyk” (placówka prowadzona przez Stowarzyszenie Na Tak), prezes Stowarzyszenia na rzecz Osób Niepełnosprawnych „Wiara i Światło". Prowadzony przez autorkę „Kamyk” to dzienna placówka terapeutyczna dla 20 osób wielorako niepełnosprawnych (tj. niepełnosprawnych intelektualnie $\mathrm{w}$ stopniu znacznym lub głębokim ze współwystępującymi takimi zaburzeniami, jak autyzm, mózgowe porażenie dziecięce, niedowidzenie, niedosłuch, sensoryzmy, epilepsja, zespół Downa, fenyloketonuria oraz inne schorzenia genetyczne, neurologiczne i metaboliczne). 
z zachowaniami seksualnymi osób wielorako niepełnosprawnych, w tym również osób z głębszą i głęboką niepełnosprawnością intelektualną. Wciąż brakuje specjalistów, którzy realizują wsparcie dorosłych osób z głęboką niepełnosprawnością. Z tego względu ośrodek prowadzony przez autorkę, wypracowując autorskie metody pracy z tą grupą osób, opierał się na doświadczeniach zagranicznych ośrodków oraz specjalistów/superwizorów z całej Polski², którzy na co dzień pracują z dziećmi głęboko niepełnosprawnymi i wspólnie z nami adaptowali znane sobie metody pracy do wspierania osób dorosłych. W kwestii wypracowania standardów pracy we wspieraniu i rozwijaniu seksualności osób wielorako niepełnosprawnych konieczna była konsultacja ze specjalistą w zakresie seksualności osób niepełnosprawnych. Podjęcie tematu seksualności w pracy z dorosłymi osobami z głęboką, złożoną niepełnosprawnością miało na celu zadbanie o podmiotowość tej grupy osób. Pośrednim rezultatem tego działania było przełamanie dominującego stereotypu seksualności osób z głęboką niepełnosprawnością intelektualną, traktującego tę grupę jako „wieczne dzieci” pozbawione potrzeb seksualnych lub nad wyraz pobudzone seksualnie, które nie potrafią kontrolować swojej seksualności.

\section{W kręgu niezależności mieszkaniowej dorosłych osób z niepełnosprawnością intelektualną}

Stereotypy na temat funkcjonowania osób z niepełnosprawnością intelektualną, mówiące iż jest to kategoria osób, która pomimo wieku biologicznego potrzebuje stałej opieki niezależnie od

${ }^{24}$ Między innymi: dr Magda Grycman - Stowarzyszenie Rehabilitacyjne Centrum Rozwoju Porozumiewania (Kwidzyń), Beata Blok, Beata Ignaczewska - Specjalny Ośrodek Rewalidacyjno-Wychowawczy dla Dzieci i Młodzieży z Autyzmem (Gdańsk), Katarzyna Klimek-Markowicz - Społeczna Szkoła Podstawowa i Społeczne Gimnazjum „Zakątek”, Jacek Kielin - Przedszkole Specjalne „Orzeszek”, Monika Karwacka - Uniwersytet im. Adama Mickiewicza (Poznań), Gill Brearley (Wielka Brytania), Fundacja Behinderten Hilfe Evangelischen Johannesstifts (Berlin). 
stopnia niepełnosprawności, są przyczyną ograniczania ich autonomii także w zakresie zamieszkania poza rodziną i poza placówką opieki całodobowej - a więc życia poza systemem bezpośredniej kontroli opiekunów. Sytuacja mieszkaniowa osób z niepełnosprawnością intelektualną jest mniej korzystna niż osób pełnosprawnych $\mathrm{w}$ tym samym wieku ${ }^{25}$. Nie mają oni niezależności mieszkaniowej, mieszkają wspólnie z rodzicami lub w warunkach całkowitej opieki w placówkach dla osób z niepełnosprawnością intelektualną. Znacząco ogranicza to budowanie tożsamości adolescentów $\mathrm{z}$ niepełnosprawnością intelektualną: ich kontakty społeczne najczęściej ograniczają się do osób z kręgu rodzinnego, hamując rozwój niezależności i poczucia odrębności od rodziców; niezależność zwykle dotyczy jedynie samoobsługi; rzadko uczestniczą oni w rozwiązywaniu sytuacji życiowych umożliwiających im doświadczanie własnej kompetencji ${ }^{26}$.

Istotą niepełnosprawności jest zależność od innych - rodziców, opiekunów, specjalistów zajmujących się dorosłymi osobami z niepełnosprawnością intelektualną. Małgorzata Kościelska wskazuje, iż „wskutek wieloletnich zaniedbań w tym względzie nie są oni przygotowani do roli osób wspomagających dorosłe życie osób upośledzonych" 27. Z tego względu najpierw w Skandynawii, obecnie również w Polsce instytucje rządowe i organizacje pozarządowe podejmują działania skierowane na rozwój systemu mieszkalnictwa wspomaganego ${ }^{28} \mathrm{w}$ dwóch podstawowych formach (ryc.):

1) mieszkania ambulatoryjne, w których wsparcie realizowane jest w postaci usług asystenckich w wymiarze godzin dostosowanym do potrzeb mieszkańców, przy braku opieki nocnej. Najczęściej są to mieszkania indywidualne lub partnerskie,

${ }^{25}$ A. Zawiślak, dz. cyt., s. 39.

26 Tamże, s. 37.

${ }_{27}$ M. Kościelska, dz. cyt., s. 8.

${ }^{28}$ Mieszkalnictwo wspomagane to zamieszkanie osoby niepełnosprawnej poza rodziną czy placówką opieki całodobowej przy odpowiednim profesjonalnym wsparciu. Wcześniej ta forma mieszkalnictwa realizowana była wśród innych kategorii osób zagrożonych ryzykiem wykluczenia społecznego, między innymi osób bezdomnych lub opuszczających placówki opiekuńczo-wychowawcze. 
2) mieszkania stacjonarne, w których wsparcie ze strony asystentów i specjalistów jest całodobowe. Zazwyczaj są to grupowe formy mieszkaniowe, na które decydują się osoby z głębszą i głęboką niepełnosprawnością intelektualną oraz osoby wielorako niepełnosprawne.

Zamieszkanie dorosłej osoby z ograniczoną sprawnością (fizyczną/sensoryczną/intelektualną) poza systemem rodzinnym i instytucjonalnym
Odbiorcami są wszyscy chętni, bez względu na rodzaj i stopień niepełnosprawności

\section{Mieszkalnictwo wspomagane}

Cel: realizowanie właściwej dla danej osoby formy niezależnego zamieszkania z adekwatną ilością i zakresem profesjonalnego wsparcia

Zakres potrzebnego wsparcia decydujące o formie zamieszkania (różne ze względu na zakres i jakość potrzebnego wsparcia)
Wymaga odpowiedniego przygotowania od okresu dzieciństwa do dorosłości, najpierw w warunkach domowych i instytucjonalnych, później w mieszkaniach treningowych (cel: nabycie kompetencji, diagnoza obszaru niezbędnego

\section{Formy mieszkaniowe}

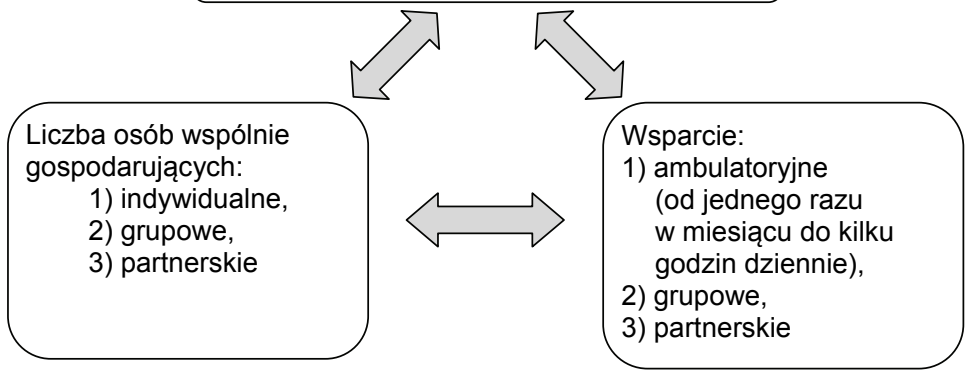

Ryc. Mieszkalnictwo wspomagane i jego formy 
W wielu krajach Europy Zachodniej i Północnej funkcjonują utrwalone wzory opuszczania domu rodzinnego po osiągnięciu wieku adolescencji. Osoby niepełnosprawne nie są wyjątkiem. W Polsce zamieszkanie osoby niepełnosprawnej poza rodziną odbywa się zazwyczaj $\mathrm{w}$ dwóch sytuacjach. Po pierwsze, gdy rodzice umierają i w rodzinie nie ma osoby, która zaopiekuje się niepełnosprawnym krewnym. Po drugie, kiedy rodzice są już starsi i nie mają sil, by wspierać swoje niepełnosprawne potomstwo. Zresztą różnica widoczna jest również $\mathrm{w}$ potocznej terminologii - w Niemczech osoba niepełnosprawna wyprowadza się z domu do grupowych form zamieszkania, w Polsce rodzina oddaje dziecko instytucji.

Samodzielne zamieszkanie osoby niepełnosprawnej intelektualnie wymaga odpowiedniego przygotowania: osoby $\mathrm{z}$ niepełnosprawnością, rodziny, otoczenia instytucjonalnego czy fizycznego. W polskim systemie wsparcia osób z niepełnosprawnością przygotowanie to swoje podstawy ma na etapie edukacji szkolnej, a później $\mathrm{w}$ środowiskowych domach samopomocy oraz $\mathrm{w}$ warsztatach terapii zajęciowej. Konieczne jest poszerzenie tego przygotowania o tzw. trening mieszkaniowy ${ }^{29}$. Istotne jest, by był on realizowany poza terenem warsztatów, mimo iż osoby $\mathrm{z}$ niepełnosprawnością mogłyby tam realizować większość zadań wpisanych w prowadzenie gospodarstwa domowego. Ważne jest, by trening mieszkaniowy realizowany był $w$ warunkach zbliżonych do naturalnych - jednak poza systemem rodzinnym i instytucjonalnym. Bowiem osoby

${ }^{29}$ Trening mieszkaniowy jest propozycją pracy terapeutycznej, której celem jest (obok elementu diagnostycznego) nabycie umiejętności związanych z samodzielnym/wspieranym zamieszkaniem. Mieszkanie treningowe jest określoną w czasie przejściową formą mieszkalnictwa. Pobyt w mieszkaniu treningowym umożliwia osobom z niepełnosprawnością intelektualną, pozostającym wcześniej pod całkowitą opieką rodziny, rozwinąć praktyczną gotowość do życia w integracji ze środowiskiem przy adekwatnym do potrzeb wsparciu trenera-asystenta. Obejmuje on m.in.: trening kulinarny, trening obsługi sprzętu gospodarstwa domowego, trening gospodarczy, trening samoobsługi, trening ekonomiczny, trening umiejętności korzystania z instytucji użyteczności publicznej, trening umiejętności korzystania z transportu publicznego, trening umiejętności społecznych, trening spędzania czasu wolnego i inne, zależnie od potrzeb osoby z niepełną sprawnością. 
z dysfunkcją intelektualną mają trudność w przenoszeniu, generalizowaniu sposobu realizacji zadań. Zasada ta ma swoje znaczenie $\mathrm{W}$ sposobie realizowania terapii. $\mathrm{W}$ jednym $\mathrm{z}$ poznańskich warsztatów terapii zajęciowej prowadzonych przez Stowarzyszenie Na Tak uczestnicy uczyli się procedury wysłania listu. Wykonywali, przy wsparciu terapeuty, ciąg czynności: od napisania listu, po włożenie go do koperty, zaadresowanie, przyklejenie znaczka i wrzucenie koperty do skrzynki na listy. W trakcie kontroli merytorycznej placówki urzędnik - widząc zakup znaczków pocztowych w kosztach programowych - podważył celowość tego zabiegu. Spytał, czy uczestnicy nie mogliby naklejać fikcyjnych znaczków, na przykład naklejek dla dzieci, to byłoby taniej. Kierownik warsztatu odpowiedział, że nie mogliby, gdyż jeśli kiedyś zdecydowaliby się wysłać list, to istnieje duże prawdopodobieństwo, że do skrzynki wrzucą kopertę z naklejonym wizerunkiem Myszki Mickey.

Dyskryminacja osób z niepełnosprawnością intelektualną w przypadku zamieszkania poza rodziną odbywa się dwutorowo:

1) ograniczanie niezależności - osoby wspierające osoby niepełnosprawne są nadopiekuńcze i nie dają im prawa do prowadzenia życia według własnego scenariusza w miejscu, w którym pozostawaliby poza bezpośrednią kontrolą rodziców;

2) niedostarczenie adekwatnego do potrzeb wsparcia (technicznego, społecznego, finansowego) - brak wsparcia w postaci asystentów, brak zabezpieczenia pieniężnego, brak udogodnień technologicznych uniemożliwia im zamieszkanie poza rodziną.

Wśród zaleceń realizatorów zadań z zakresu mieszkalnictwa treningowego ${ }^{30}$ funkcjonuje zasada: „dobry asystent to leniwy asystent". Osoby z niepełnosprawnością mają prawo prowadzić niezależne życie w takim wymiarze, jakiego potrzebują. Istotne jest trenowanie umiejętności proszenia o pomoc. W przeciwnym wypadku

30 Stowarzyszenie Na Tak od 2008 r. realizuje zadanie zlecane przez Państwowy Fundusz Rehabilitacji Osób Niepełnosprawnych oraz współfinansowane ze środków Unii Europejskiej, w ramach którego prowadzi dwa mieszkania treningowe dla osób z niepełnosprawnością intelektualną. 
asystent może ingerować $\mathrm{w}$ życie swojego klienta w zbyt wielu zakresach, odbierając mu prawo do decydowania o sobie. Wiąże się z tym też "prawo do niezdrowego życia” realizowane w berlińskiej fundacji Evangelisches Johannesstift - jeśli osoba niepełnosprawna chce palić papierosy, nie chce wietrzyć pokoju, nie przeszkadza jej bałagan - asystent nie może $\mathrm{w}$ to ingerować. Sprawnych osób, którzy opuścili dom rodzinny w okresie adolescencji, żadna instytucja nie kontroluje, czy mają posprzątane i wywietrzone mieszkanie. Zauważa się prawidłowość, iż poziom kontroli i oceny osób dorosłych jest zależny od występowania niepełnosprawności niezależnie od jej stopnia.

\section{Uwagi końcowe}

Podsumowując poczynione rozważania, należy stwierdzić, że dyskryminacja osób z niepełną sprawnością ma miejsce wszędzie tam, gdzie obecne są stereotypy na temat potrzeb i możliwości dorosłych osób z ograniczoną sprawnością intelektualną, szczególnie $\mathrm{w}$ obszarach, $\mathrm{w}$ których całkowita kontrola jest niemożliwa $\mathrm{z}$ natury rzeczy. Należy pamiętać, że w dorosłość wpisane są cechy wspierające budowanie tożsamości: przyjęcie odpowiedzialności za własne działania, autonomia, podejmowanie decyzji i działań, opierając się na własnych przekonaniach i wartościach, uniezależnienie się od wpływu rodziców, a także wejście z nimi w stosunki partnerskie ${ }^{31}$. Kierowanie się postawami ograniczającymi doświadczenia osób niepełnosprawnych intelektualnie $w$ tym zakresie negatywnie wpływa na rozwój ich podmiotowości, autonomii, poczucia kompetencji, tj. wartości wpływających w znacznej mierze na rozwój tożsamości, autopercepcję i jakość życia.

Zmiana negatywnych postaw jest możliwa, wymaga jednak spojrzenia na osobę ponad jej fizycznym czy intelektualnym ograni-

31 J.J. Arnett, Conceptions of the Transition to Adulthood: Perspectives From Adolescence Through Midlife, "Journal of Adult Development" 2001, Vol. 8, No. 2, s. 133. 
czeniem. Jest to trudne zarówno dla rodziców, którzy mimo wieku biologicznego wciąż zapewniają wsparcie swoim dzieciom w realizacji wielu życiowych czynności - pełnią rolę opiekunów (często prawnych opiekunów) i to wyznacza im kierunek działań. Jest to trudne również dla terapeutów, którzy w swojej pracy na osoby niepełnosprawne patrzą z perspektywy deficytu. Jest to generowane nie tylko przez sposób, w jaki zostali przygotowani do roli terapeuty, ale też przez odgórne wymogi związane $z$ realizowaniem określonych celów rehabilitacyjnych i osiąganiem efektów w procesie terapeutycznym - zawsze w osobie niepełnosprawnej jest coś, co musi zostać naprawione.

Osią zmian w realizowaniu wsparcia dla osób niepełnosprawnych powinna być Konwencja Organizacji Narodów Zjednoczonych o prawach osób niepełnosprawnych ${ }^{32}$, której celem jest popieranie oraz ochrona praw i godności osób niepełnosprawnych. Wsparcie rozwoju osób z niepełnosprawnością wymaga od pedagogów, psychologów, terapeutów, rodziców, decydentów organizowania pomocy $\mathrm{w}$ sposób umożliwiający niepełnosprawnemu adolescentowi realizację potrzeb związanych z budowaniem tożsamości (autonomii, kompetencji, partnerskich relacji). Konieczne jest zatem poszanowanie decyzji, wartości, indywidualności osoby niepełnosprawnej. Warto przyjąć za Franciszkiem Wojciechowskim³3, że umożliwienie rozwoju adolescenta od znaczących dla niego osób wymaga towarzyszenia (fizycznego, psychicznego), a nade wszystko spotkania, gdzie możliwe będzie prawdziwe partnerstwo, bezpośredniość

32 Konwencja ONZ o prawach osób niepełnosprawnych została ratyfikowana przez Polskę 6 września $2012 \mathrm{r}$. W konwencji znalazły się zapisy dotyczące prawa do realizowania niezależnego życia, również w zakresie seksualności i zamieszkania. $W$ art. 11 zapisano, że „osoby niepełnosprawne będą miały możliwość wyboru miejsca zamieszkania i podjęcia decyzji co do tego, gdzie i z kim będą mieszkać, na zasadzie równości z innymi osobami, a także, że nie będą zobowiązywane do mieszkania w szczególnych warunkach". Konwencja zakłada również, iż formy pomocy i wsparcia będą dostosowane do wieku, płci i niepełnosprawności (art. 16 pkt 4 Konwencji o prawach osób niepełnosprawnych, Tekst opublikowany w Dzienniku Ustaw w dn. 25 października 2012 r., poz. 1169).

${ }^{3}$ Por. F. Wojciechowski, dz. cyt., s. 69. 
i pełna akceptacja. Spojrzenie na osobę z ograniczoną sprawnością jak na osobę mającą takie same potrzeby, jak każdy człowiek, bez względu na jego płeć, rasę czy sprawność, wymaga zmiany perspektywy: z tego, co dla mnie jest ważne, na to, co jest ważne dla osoby z niepełnosprawnością.

\section{Bibliografia}

ARNETT J.J., Conceptions of the Transition to Adulthood: Perspectives From Adolescence Through Midlife, "Journal of Adult Development" 2001, Vol. 8, No. 2.

BREARLEY G., Presentation: where did I come from?, Petnoprawni seksualnie - materiaty pokonferencyjne, materiały pokonferencyjne - Stowarzyszenie Na Tak, Poznań 2011.

CHRUŚCIAK M., MiCHALCZUK J., SIJKO K., WISZEJKO-WIERZBICKA D., ŻYCZYŃSKA-CIOŁEK D., Bariery aktywności zawodowej oraz czynniki sprzyjające podejmowaniu i utrzymywaniu pracy, [w:] W. Łukowski, Osoby z ograniczona sprawnością na rynku pracy - portret środowiska, SWPS Academia, Warszawa 2008.

DYKCIK W., Tendencje rozwoju pedagogiki specjalnej. Osiagnięcia naukowe i praktyka (z perspektywy 50-lecia pracy pedagogicznej z osobami z niepetnosprawnościa), Wyd. Nauk. Polskiego Towarzystwa Pedagogicznego Oddział w Poznaniu, Poznań 2010.

GOFFMAN E., Piętno. Rozważania o zranionej tożsamości, GWP, Gdańsk 2005.

GOLKA M., Socjologia kultury, Wyd. Nauk. Scholar, Warszawa 2007.

KOŚCIELSKA M., Niechciana seksualność, Jacek Santorski \& Co, Warszawa 2004.

PAWELCZAK K., KARWACKA M., Granice spotecznego przyzwolenia na realizacje praw seksualnych osób z niepetnosprawnościa, Impuls, Kraków 2013 [artykuł w druku].

RĘKOSIEWICZ M., $W$ drodze do dorostości. Tożsamość osób z niepetnosprawnościa intelektualna, TIPI, Wielichowo 2012.

WOJCIECHOWSKI F., Problemy adolescencji. Postępowanie profilaktyczne $i$ pomocowe w kontekście niepetnosprawności, [w:] T. Żółkowska (red.), Społeczno-pedagogiczne konteksty niepetnosprawności, US, Szczecin 2011.

WOŹNIAK Z., Niepetnosprawność i niepetnosprawni w polityce spotecznej. Społeczny kontekst medycznego problemu, SWPS Academia, Warszawa 2008.

ZAWIŚLAK A., Jakość życia osób dorostych z niepetnosprawnością intelektualną, DIFIN, Warszawa 2011.

Dokumenty

Ustawa z dnia 25 lutego 1964 r. Kodeks rodzinny i opiekuńczy, art. 12 § 1.

Ustawa z dnia 6 czerwca 1997 r. Kodeks karny, art. 197-198.

Konwencji o prawach osób niepełnosprawnych, Tekst opublikowany w Dzienniku Ustaw w dnia 25 października 2012 r., poz. 1169. 